\title{
Physicochemical and Functional Characterization of Cocosin, the Coconut 11S Globulin
}

\author{
Mark Rickard N. Angelia ${ }^{1,2}$, Roberta N. Garcia ${ }^{1}$, Kristian Mark P. CALdo ${ }^{1,2}$, Krisna PraK ${ }^{3}$, Shigeru Utsumi ${ }^{3}$ and \\ Evelyn Mae TeCson-MendozA ${ }^{1 *}$
${ }^{1}$ Institute of Plant Breeding, Crop Science Cluster, College of Agriculture, University of the Philippines Los Baños, College, Laguna 4031, Philippines
${ }^{2}$ Institute of Chemistry, College of Arts and Sciences, University of the Philippines Los Baños, College, Laguna 4031, Philippines
${ }^{3}$ Laboratory of Food Quality Design and Development, Division of Agronomy and Horticultural Science, Graduate School of Agricul- \\ ture, Kyoto University, Uji, Kyoto 611-0011, Japan
}

Received June 8, 2009; Accepted January 21, 2010

The physicochemical and functional characteristics of the major coconut storage protein, 11S globulin or cocosin, were investigated. Cocosin was purified by a combination of salt extraction, selective precipitation, and gel filtration chromatography. The solubility of cocosin at different $\mathrm{pH}$ was higher at $\boldsymbol{\mu}=0.5$ than at $\boldsymbol{\mu}=\mathbf{0 . 0 8}$. The 24 and $21 \mathrm{kDa}$ basic polypeptides of cocosin were more resistant to chymotrypsin digestion than the 35 and $32 \mathrm{kDa}$ acidic polypeptides. Cocosin emulsions were most stable at $0 \mathrm{M} \mathrm{NaCl}$, followed by emulsions in $0.1 \mathrm{M}$ and $0.4 \mathrm{M} \mathrm{NaCl}$. The available $\mathrm{SH}$ groups were found to be $21.6 \mathrm{~mole} \mathrm{SH} / \mathrm{mole}$ cocosin. Cocosin was observed to be stable under various pasteurization conditions from $63^{\circ} \mathrm{C}, 30 \mathrm{~min}$ to $100^{\circ} \mathrm{C}, 10 \mathrm{sec}$. However, heating at $100^{\circ} \mathrm{C}$ for $10 \mathrm{~min}$ and longer degraded cocosin up to $60 \%$. The thermal denaturation midpoint temperature, $T_{m}$, of the trimeric cocosin was $77.6^{\circ} \mathrm{C}$ while that of the hexameric form was $100.5^{\circ} \mathrm{C}$.

Keywords: coconut, globulins, cocosin, storage proteins, emulsifying ability, solubility, thermal denaturation

\section{Introduction}

The solid endosperm of coconut, Cocos nucifera L., contains $45-55 \%$ oil and about $8 \%$ protein most of which remains in the residue after oil extraction. The abundance of coconut all year round and its wide distribution in the Philippines and other tropical countries make it a potential source of proteins for animal and human consumption.

The major coconut protein in the endosperm is the $11 \mathrm{~S}$ globulin or cocosin. Previous studies by Garcia et al. (2005) indicated that cocosin amounted to $86 \%$ of the total globulins while $7 \mathrm{~S}$ was only $14 \%$. Cocosin is a hexamer and was initially reported as having a molecular weight of $208 \mathrm{kDa}$ (Sjögren and Spychalski, 1930), although recent reports suggest a higher value of $326 \mathrm{kDa}$ (Garcia et al., 2005). Each subunit of cocosin is composed of acidic and basic polypeptides linked together via a single disulfide bond. Garcia et al. (2005) further reported the presence of carbohydrates in the basic polypeptides of cocosin. Carr et al. (1990) also noted

*To whom correspondence should be addressed. E-mail: emtmendoza@nast.ph,emtmphil@yahoo.com the heterogeneity of the subunits, a characteristic common to all $11 \mathrm{~S}$ seed proteins. Cocosin is also readily crystallized, although evidences show that several forms of the protein exist (Balasundaresan et al., 2002; Carr et al., 1990; Garcia et al., 2005).

Earlier studies on the functional properties of coconut proteins utilized protein concentrates (Kwon et al., 1996a, b; Kwon and Rhee, 1996) which would include both globulins and albumins. Proteins were extracted from undefatted solid endosperm at $\mathrm{pH} 7$ using $0.5 \mathrm{M} \mathrm{NaCl}$ solution followed by ultrafiltration resulted in concentrates with about $52 \%$ protein (Kwon et al., 1996b). They further observed that coconut protein concentrates had similar oil absorption values, lower water absorption values and higher emulsifying ability compared with those of soy protein concentrate and $\mathrm{Na}$-caseinate. Solubility of coconut proteins in high salt solution was lowest at $\mathrm{pH}<2$ and increased as $\mathrm{pH}$ increased (Samson et al., 1971; Kwon and Rhee, 1996). On the other hand, coconut proteins in water had isoelectric point or minimum solubility at $\mathrm{pH} 4$ to 5 and solubility increased at both sides of this $\mathrm{pH}$. Kwon et al. (1996b) reported that differential scanning calorimetry 
(DSC) analysis showed coconut albumins to have endothermic peaks of $94^{\circ} \mathrm{C}$ while globulins had 92,98 and $112^{\circ} \mathrm{C}$.

The food products that are commonly produced from coconut are oil, desiccated coconut, and coconut water beverage. With the increasing emphasis and demand for new healthy products by a consumer society, coconut proteins could be utilized in the development of processed foods and in fluid protein systems like the increasing popular proteinbased beverages.

Initial studies on cocosin have provided the basic information needed for further characterization of the protein. However, if cocosin is to be used as ingredient for food systems, its functional properties must be examined. In line with our efforts to study intensively the oil and proteins of coconut, we conducted further characterization of cocosin and the determination of its physicochemical and functional properties toward its commercial applications in food systems.

\section{Materials and Methods}

Sample The mature coconut (11-12 mo) var Laguna Tall was obtained from the Institute of Plant Breeding, Crop Science Cluster, College of Agriculture, University of the Philippines Los Baños, College, Laguna, Philippines.

Extraction of proteins The extraction of coconut proteins was done according to the method of Garcia et al. (2005). The mature coconut endosperm was grated then ground in liquid nitrogen. The ground endosperm was defatted twice by adding $n$-hexane $(1: 10 \mathrm{w} / \mathrm{v})$ then stirred for $1 \mathrm{~h}$. The defatted meal was then dried overnight under the hood. To twenty grams of the defatted meal was added $360 \mathrm{~mL}$ of extraction buffer (35 mM potassium phosphate buffer, $\mathrm{pH} 7.6$ with 0.4 $\mathrm{M} \mathrm{NaCl}, 0.1 \mathrm{mM}$ PMSF, $10 \mathrm{mM} \beta$-mercaptoethanol, $0.02 \%$ sodium azide, $1 \mathrm{mM}$ EDTA) to extract the total proteins. The mixture was then placed in an ice bath and stirred for $1 \mathrm{~h}$. The homogenate was filtered by passing through four layers of cheesecloth and further clarified by centrifugation at 23500 $\times g$ for 15 min using a Sorvall RC5B refrigerated centrifuge. The clarified supernatant was then collected and subjected to selective precipitation.

Selective precipitation The clarified crude extract was dialyzed for 48 hours against distilled water containing 10 $\mathrm{mM} \beta$-mercaptoethanol. The dialysate was centrifuged for 15 $\min$ at $23500 \mathrm{x}$ g to collect the globulin precipitate. The precipitate was further washed three times with distilled water containing $10 \mathrm{mM} \beta$-mercaptoethanol. The globulin precipitate was resuspended in minimum amount of buffer and then subjected to gel filtration chromatography.

Gel filtration by Fast Protein Liquid Chromatography All reagents and samples for Fast Protein Liquid Chromatography (AKTA FPLC Chromatographic System, Amersham
Biosciences) were filtered through $0.22 \mu \mathrm{m}$ Millipore membranes. Eighty milligrams of globulin with a total volume of $13 \mathrm{~mL}$ were loaded onto a HiLoad 26/60 Superdex 200 (Amersham Pharmacia) column attached to the FPLC equipment and eluted with buffer which had the same components as the extraction buffer at a flow rate of $1 \mathrm{~mL} / \mathrm{min}$. Fractions $(3 \mathrm{~mL})$ were routinely analyzed by sodium dodecyl sulfatepolyacrylamide gel electrophoresis (SDS-PAGE). Fractions containing the $11 \mathrm{~S}$ globulins were pooled and kept at $4^{\circ} \mathrm{C}$ until further characterization.

Sodium dodecyl sulfate-polyacrylamide gel electrophoresis Electrophoresis was done according to the method described by Laemmli (1970). SDS-PAGE was performed on $11 \%$ discontinuous denaturing gels using a minigel electrophoresis apparatus (BIORAD). Protein samples were run at $110 \mathrm{~V}$ for $1 \mathrm{~h}$ and $30 \mathrm{~min}$ then stained with $0.25 \%$ Coomassie blue R250 for 20-30 min. The gels were destained with $40 \%$ methanol-7\% acetic acid in water solution. Molecular weight of the subunits were estimated using a MARK12 WideRange Unstained Standard for SDS-PAGE consisting of the following proteins: myosin $(200 \mathrm{kD}), \beta$-galactosidase $(116.3$ $\mathrm{kD})$, phosphorylase B $(97.4 \mathrm{kD})$, bovine serum albumin $(66.3$ $\mathrm{kD})$, glyceraldehyde dehydrogenase $(55.4 \mathrm{kD})$, lactate dehydrogenase $(36.5 \mathrm{kD})$, CAH (31 kD), trypsin Inhibitor (21.5 $\mathrm{kD})$, lysozyme $(14.4 \mathrm{kD})$, aprotinin $(6 \mathrm{kD})$, insulin $\mathrm{B}$ chain (3.5 kD), insulin A chain $(2.5 \mathrm{kD})$.

Densitometric analysis The electropherograms were scanned and the resulting images were analyzed using the Scion Image software (Scion Corporation) to determine the percent composition of the different proteins.

Solubility in different $\mathrm{pH}$ The solubility of cocosin at different $\mathrm{pH}$ and ionic strength was studied with the following buffer systems: $0.1 \mathrm{M}$ citric acid-0.2 $\mathrm{M} \mathrm{Na}_{2} \mathrm{HPO}_{4}(\mathrm{pH}$ 3.4-6.4); 0.5 $\mathrm{M} \mathrm{NH}_{4} \mathrm{Cl}-0.1 \mathrm{M} \mathrm{NH}_{4} \mathrm{OH}$ (pH 6.3-9.0). Higher ionic strengths were obtained by addition of $\mathrm{NaCl}$.

The cocosin samples $(500 \mu \mathrm{L})$, containing $2.5 \mathrm{mg} / \mathrm{mL}$ protein, were dialyzed for $18 \mathrm{~h}$ at $4^{\circ} \mathrm{C}$ against buffers of varying $\mathrm{pH}$ at low $(\mu=0.08)$ and high $(\mu=0.5)$ ionic strength. After dialysis, the samples were recovered by centrifugation for 5 min at $20800 \times g$ at $4^{\circ} \mathrm{C}$ using an Eppendorf $5417 \mathrm{C}$ refrigerated centrifuge. The amount of protein in each sample was determined by Bradford method (1976) using BSA as protein standard. The solubility was expressed as a percentage of the total protein content in the sample.

$\alpha$-Chymotrypsin digestion All cocosin samples were previously dialyzed against $35 \mathrm{mM}$ potassium phosphate buffer ( $\mathrm{pH}$ 7.6). Two-and-a-half microliters of $1 \mathrm{mg} / \mathrm{mL}$ chymotrypsin was mixed with $20 \mu \mathrm{L}$ of $0.5 \mathrm{mg} / \mathrm{mL}$ cocosin sample. The mixtures were allowed to react at specified times $(3,5,10,20,30,60 \mathrm{~min})$ at room temperature. The control 
contained $2.5 \mu \mathrm{L}$ extraction buffer instead of enzyme solution. The digestion was stopped by boiling the samples for 5 min. After boiling, the samples were immediately kept on ice for another $5 \mathrm{~min}$. Samples were subjected to SDS-PAGE to determine the degree of digestion.

Stability of emulsions Samples of cocosin were dialyzed against $35 \mathrm{mM}$ potassium phosphate buffer containing increasing amounts of $\mathrm{NaCl}(0,0.1$, and $0.4 \mathrm{M})$. After dialysis, the protein content of the samples was adjusted to $1 \mathrm{mg} /$ $\mathrm{mL}$. Stability of emulsions was then determined according to the method of Soares et al. (2004) with some modifications. Emulsions were prepared by adding $0.25 \mathrm{~mL}$ soybean oil to $1.5 \mathrm{~mL}$ of the protein solution followed by homogenization for $30 \mathrm{~s}$ at maximum rpm using a Heidolph Diax 900 homogenizer. This was followed by 1 min sonication at 100 $\mu \mathrm{A}$ using a Branson Cell Disruptor 185 sonicator. A $100 \mu \mathrm{L}$ reaction mixture was obtained from the bottom of the tubes at different time intervals and diluted with $4.9 \mathrm{~mL}$ of $0.1 \%(\mathrm{w} /$ v) solution of sodium dodecyl sulfate. Absorbance was then measured at $500 \mathrm{~nm}$. Emulsion stability was estimated by the duration of the emulsion formed over time up to 10 minutes. Furthermore, emulsions were allowed to stand at room temperature without agitation and visually observed for several hours to evaluate stability.

Number of sulfhydryl groups Determination of the total protein sulfhydryl was performed according to the modified Ellman method (Ellman, 1959; Habeeb, 1975). The molar concentration of sulfhydryl groups was quantified using a molar absorptivity of $13600 \mathrm{M}^{-1} \mathrm{~cm}^{-1}$. Positive controls, such as BSA and cysteine, were used to validate the method.

Determination of the available protein sulfhydryl was performed as described above, but in the absence of SDS. The amount of protein in each sample was determined by Bradford method (1976) using BSA as protein standard.

Thermal Stability of Cocosin Cocosin $(113 \mu \mathrm{g}$ in $100 \mu \mathrm{L}$ ) was subjected to two heat treatment regimes to assess its thermal stability. In the first experiment, cocosin was incubated at $100^{\circ} \mathrm{C}$ for $10,20,30,40,50$ and $60 \mathrm{~min}$. In the second experiment, cocosin was subjected to different pasteurization conditions commonly used in food processing. The treatments were: $63^{\circ} \mathrm{C}, 30 \mathrm{~min} ; 69^{\circ} \mathrm{C}, 30 \mathrm{~min} ; 72^{\circ} \mathrm{C}, 16$ sec; $75^{\circ} \mathrm{C}, 10 \mathrm{~min} ; 80^{\circ} \mathrm{C}, 25 \mathrm{sec} ; 100^{\circ} \mathrm{C}, 12 \mathrm{sec}$; and $121^{\circ} \mathrm{C}$, $15 \mathrm{~min}$. After each time interval, the sample was removed from heat and kept on ice until all samples were ready for SDS-PAGE analysis. SDS-PAGE was done as previously described but this time, under non-reducing conditions. The amount of remaining cocosin monomer was estimated by scanning the gels and the image analyzed using Scion Image.

Differential scanning calorimetry The thermal stability of cocosin was further analyzed using a Microcal MC-2 ultrasensitive microcalorimeter (Microcal Inc.). The heating rate was set at $5^{\circ} \mathrm{C} / \mathrm{min}$ over the range of $30-110^{\circ} \mathrm{C}$. All analyses were performed with a protein concentration of 2.5 $\mathrm{mg} / \mathrm{mL}$ in $35 \mathrm{mM}$ potassium phosphate buffer, $\mathrm{pH} 7.6$ with 0.4 $\mathrm{M} \mathrm{NaCl}, 0.1 \mathrm{mM}$ PMSF, $10 \mathrm{mM} \beta$-mercaptoethanol, $0.02 \%$ sodium azide, $1 \mathrm{mM} \operatorname{EDTA}(\mu=0.5)$.

\section{Results and Discussion}

Purification of cocosin The coconut globulins were effectively separated from the albumin fraction during the initial stages of purification. The SDS-PAGE profiles of the total proteins, globulins, and albumins are shown in Figure 1. The globulin fraction was resolved into 7 major polypeptides while the albumin fraction resolved into 3. Kwon et al. (1996b) noted that majority of the coconut proteins are globulins amounting to $40-75 \%$ while albumins are only 21 $25 \%$ of the total extractable proteins. Other minor coconut proteins that occur at less than $15 \%$ of the total extractable proteins include prolamines, glutelins-1, and glutelins-2 (DeMason and Sekhar, 1990; Kwon et al., 1996b).

The 11S (cocosin) was further separated and purified by subjecting the globulin fraction to gel filtration chromatography. The major peak with molecular weight of about $320 \mathrm{kDa}$ corresponded to cocosin and had an electrophoretic pattern (Fig. 1) similar to that reported by Garcia et al. (2005).

Solubility at different $p H \quad$ The solubility profile of cocosin at different $\mathrm{pHs}$ was higher at high ionic strength $(\mu=0.5)$ than at low ionic strength $(\mu=0.08)$ (Fig. 2). At low ionic strength, cocosin exhibited minimum solubility of $12.4 \%$ at pH 5.4 which may represent its isoelectric point, while maximum solubility of $72.3 \%$ was observed at $\mathrm{pH}$ 8.2. Coconut protein concentrates were observed to have minimum solubil-

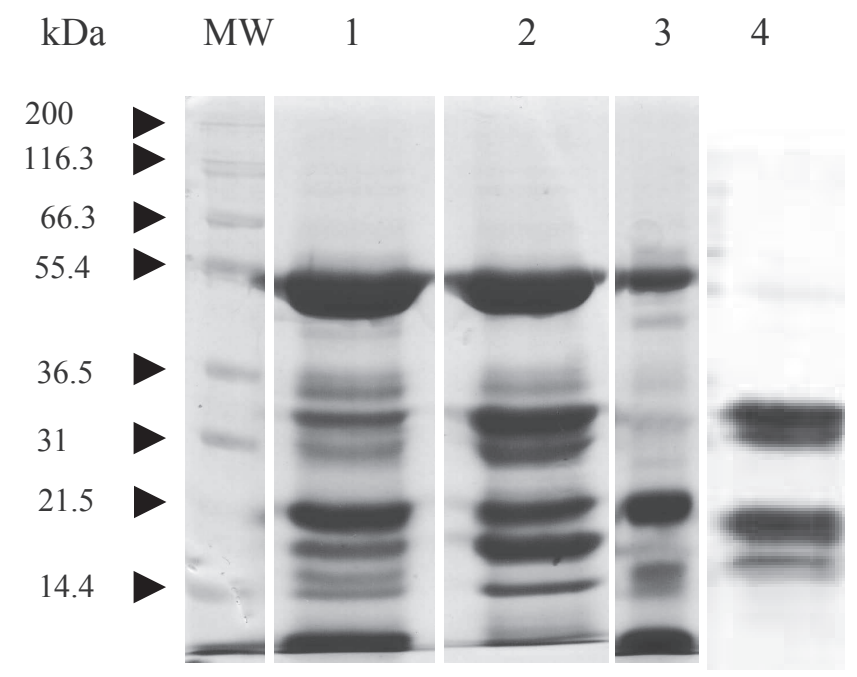

Fig. 1. SDS-PAGE profiles of the different coconut proteins following extraction. Lane (MW) molecular weight markers; (1) coconut total proteins; (2) globulins; (3) albumins; (4) purified cocosin. 


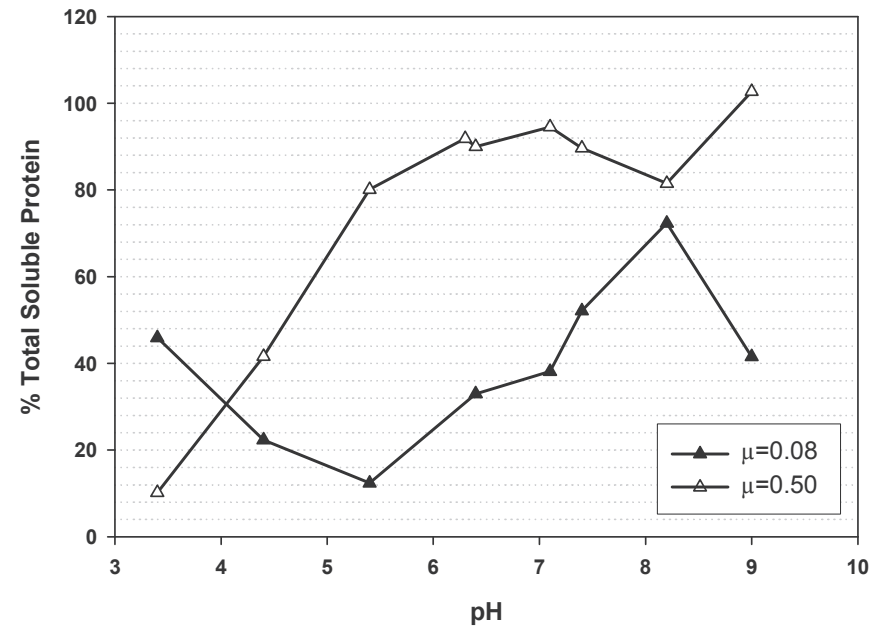

Fig. 2. Solubility of cocosin at different $\mathrm{pH}$ and ionic strength.

ity at pH 4 to 5 (Kwon et al., 1996a; Kwon and Rhee, 1996; Samson et al., 1971). The results are in agreement with those obtained by Gueguen et al. (1988) for pea legumin which was also appreciably precipitated and aggregated between pH 3.5 and 5.8. The U-shaped solubility profile of cocosin at $\mu=0.08$ is also typical for most food proteins, with minimum solubility occurring at the isoelectric $\mathrm{pH}$ (Damodaran, 1996). The 11S globulins from the wild-type and mutant cultivars of soybean (Mori et al., 2004; Rickert et al., 2004) as well as cruciferin (Mohamad Ramlan et al., 2002) also exhibited similar low solubility profiles at acidic $\mathrm{pH}$ due to isoelectric precipitation.

Cocosin was $80-100 \%$ soluble across $\mathrm{pH}$ 5.4-9.0 at $\mu=0.5$. However, the solubility rapidly decreased below $\mathrm{pH} 5.4$ with a minimum solubility of $10.2 \%$ observed at $\mathrm{pH} 3.4$. This trend is also observed with other $11 \mathrm{~S}$ globulins from soybean (Maruyama et al., 2004) and rapeseed (Mohamad Ramlan et al., 2002). Maruyama et al. (2004) correlated the solubility of wild-type and mutant soybean $11 \mathrm{~S}$ globulins with the amount of acidic amino acids present. They suggested that $11 \mathrm{~S}$ globulins containing high amounts of acidic amino acids have lower solubility in acidic $\mathrm{pH}$. Hence for cocosin, the levels of acidic amino acids may contribute a significant role in predicting its solubility behavior.

$\alpha$-Chymotrypsin digestion Digestibility of a protein is important as it is indicative of its nutritional quality. The enzymatic digestibility of cocosin using $\alpha$-chymotrypsin was evaluated at various time intervals, ranging from 3 to $60 \mathrm{~min}$. The extent of proteolysis was then determined by running the samples on SDS-PAGE. Three cocosin polypeptides were found to be fairly resistant to chymotrypsin digestion while one polypeptide was easily digested (Fig. 3). In particular, the $35 \mathrm{kDa}$ polypeptide was completely digested after only $5 \mathrm{~min}$ of reaction, as shown by the complete disappearance of the band on SDS-PAGE. On the other hand, polypeptides 32, 24, and $21 \mathrm{kDa}$ were digested to different extents after $60 \mathrm{~min}$ of reaction with chymotrypsin. Densitometric analysis reveals that $38 \%$ of polypeptide $32 \mathrm{kDa}$ remained after 60 min while $58 \%$ and $56 \%$ remained for polypeptides 24 and $21 \mathrm{kDa}$, respectively. Several low molecular weight bands of digestion products appeared after 3 min of digestion.

The results further reveal differences in susceptibility to proteolytic digestion between the acidic polypeptides of cocosin. As seen in Figure 3, the $35 \mathrm{kDa}$ subunit is more susceptible to digestion as compared with the $32 \mathrm{kDa}$. This vulnerability to digestion may indicate differences in amino acid content and sequence and may suggest a greater number of cleavage sites in the $35 \mathrm{kDa}$ isoform.

In terms of susceptibility between the acidic and basic polypeptides of cocosin, the basic polypeptides (24 and 21 $\mathrm{kDa})$ were shown to be more resistant to degradation and were digested to similar extents after $60 \mathrm{~min}$ of reaction. Similar trends were observed for glycinin upon digestion with clostripain (Lakemond et al., 2000) and this greater susceptibility to digestion of acidic polypeptides of glycinin was attributed to their higher overall relative exposure or accessibility. Mills et al. (2002) also reported that only the acidic polypeptides of glycinin were digested by trypsin and chymotrypsin while the basic polypeptides remained intact. Coconut products such as coconut meal, defatted coconut meal and full fat-coconut protein concentrate were found to have high protein digestibility values of $88.75 \%, 89.30 \%$ and 94.02\%, respectively (Mepba and Achinewhu, 2003).

Stability of emulsions The emulsifying property of cocosin at different levels of $\mathrm{NaCl}(0,0.1$, and $0.4 \mathrm{M})$ was evaluated by visual observation of the stability of emulsions (Fig. 4). Visual observation indicated that emulsions are most stable in $0 \mathrm{M} \mathrm{NaCl}$ followed by cocosin in $0.1 \mathrm{M}$ and $0.4 \mathrm{M}$

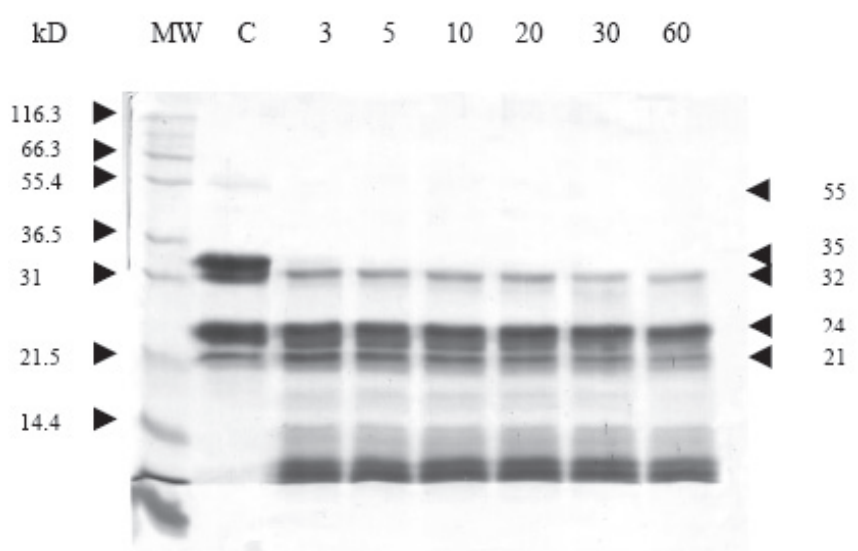

Fig. 3. SDS-PAGE profile of the chymotrypsin digestion of cocosin. Lane MW - molecular weight marker; C - control; 3, 5, 10, 20, 30, 60 - time (in minutes) of digestion. 


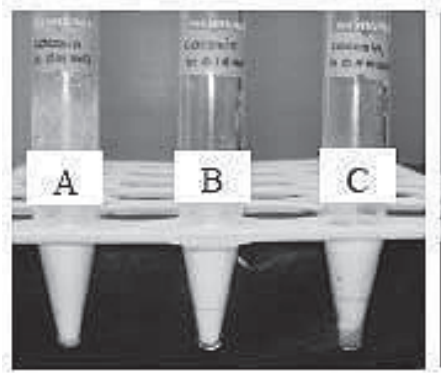

$0 \min$

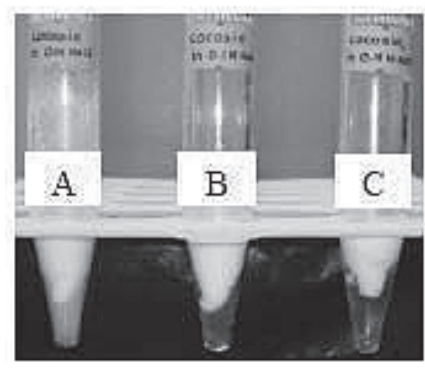

$30 \mathrm{~min}$

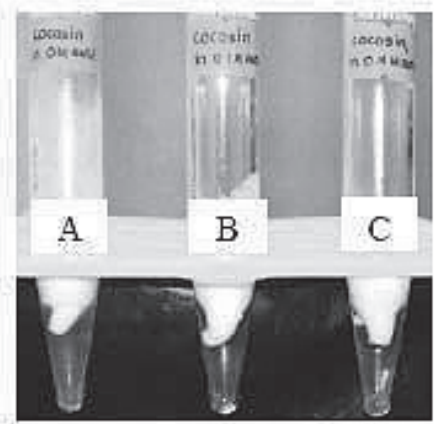

$140 \mathrm{~min}$

Fig. 4. Emulsions formed between cocosin and soybean oil at different concentrations of NaCl. (A) $0 \mathrm{M} \mathrm{NaCl}$; (B) $0.1 \mathrm{M} \mathrm{NaCl}$; (C) $0.4 \mathrm{M} \mathrm{NaCl}$.

$\mathrm{NaCl}$, respectively. Stability of emulsions lasted for more than $60 \mathrm{~min}$ in $0 \mathrm{M} \mathrm{NaCl}$ while creaming and separation was already evident after only 10 min standing in $0.4 \mathrm{M} \mathrm{NaCl}$. Stability of emulsion for cocosin in $0.1 \mathrm{M} \mathrm{NaCl}$ was intermediate and separation was observed after $30 \mathrm{~min}$. These results were further confirmed by determining the turbidity at 500 $\mathrm{nm}$ (data not shown). Emulsions made with cocosin in $0 \mathrm{M}$ $\mathrm{NaCl}$ exhibited the highest turbidity throughout the analysis indicating that cocosin was more efficient in dispersing oil particles in the absence of $\mathrm{NaCl}$. The emulsifying properties of cocosin in $0.1 \mathrm{M}$ and $0.4 \mathrm{M} \mathrm{NaCl}$ have very close and similar profiles. The coconut protein concentrate exhibited a similar characteristic of higher emulsifying ability in the absence of salt (Kwon et al., 1996a; Kwon and Rhee, 1996).
This particular behavior of cocosin is contrary to what was observed for other $11 \mathrm{~S}$ globulins, in particular for glycinin and cruciferin. Better emulsifying ability was exhibited by glycinin and cruciferin when the ionic strength $(\mu=0.5)$ or salt concentration was high (Mohamad Ramlan et al., 2002). On the other hand, sunflower total seed proteins also had similar emulsifying characteristic as coconut globulins and protein concentrate (Venktesh and Prakash, 1993). This characteristic of cocosin may find unique applications in foods and food ingredients that require low salt concentrations.

Number of sulfhydryl groups The total protein sulfhydryl of cocosin was not measured due to extensive precipitation upon addition of SDS. Hence, only the available protein sulfhydryl was determined.

The calculated available protein sulfhydryl yielded a value of $21.6 \mathrm{~mol} \mathrm{SH} / \mathrm{mol}$ cocosin (data not shown). Bovine serum albumin was found to have $0.50 \mathrm{~mol} \mathrm{SH} / \mathrm{mol} \mathrm{BSA}$, which was similar to previously reported values (Reiner $e t$ al., 2002). Determination of the amount of cysteine yielded a value of $8.967 \times 10^{-5} \mathrm{M} \mathrm{SH}$ which was close to the actual amount of $1.02 \times 10^{-4} \mathrm{M} \mathrm{SH}$. The amount of SH and SS detected by Ellman's reagent may significantly vary depending upon the method of protein preparation used and the presence of reducing agents (Hoshi and Yamauchi, 1983; Wolf, 1993). For instance, the presence of 2-mercaptoethenol in the extraction buffer of cocosin may cleave disulfide bonds located on the protein surface. As a consequence, an apparent increase in the surface SH may be observed.

The minimum number of $\mathrm{SH}$ groups expected in a glycinin hexamer is 12 (Utsumi et al., 1997; Wolf, 1993). However, the value obtained from cocosin was higher. It is also difficult to account for the exact number of SH groups per subunit of cocosin. This complication may be due to the heterogeneity and multiplicity of the subunits purified. Some subunits may contain slightly greater amounts of SH or SS groups than the other subunits. This was also demonstrated in glycinin, with the group I subunits having three SS groups while the group II subunits contained only two SS groups (Utsumi et al., 1997).

In general, 11S globulins contain two highly conserved disulfide bonds. One is an intrachain disulfide bond present within the acidic polypeptide while the other is an interchain disulfide bond linking the acidic and basic polypeptides (Hortsmann, 1983; Shewry et al., 1995; Staswick et al., 1984). The interchain disulfide bond was already known to be present in cocosin (Garcia et al., 2005) while the intrachain disulfide bond is yet to be established.

Thermal stability Proteins tend to undergo structural changes when exposed to heat. The hydrophobic chains of proteins are exposed during heat treatment which may lead to 
irreversible aggregation.

(a) Heat treatment at $100^{\circ} \mathrm{C}$. After $10 \mathrm{~min}$ of incubation at $100^{\circ} \mathrm{C}$, the cocosin band at $55 \mathrm{kDa}$ representing the complete monomer (basic and acidic subunits) had decreased by $10 \%$ resulting in the formation of high molecular weight bands indicating the occurrence of aggregation (Fig. 5a, see arrow). The level of aggregation increased progressively as heating time was increased while the amount of the cocosin band decreased to $40 \%$ after $60 \mathrm{~min}$ (Fig. 5b).

(b) Under different pasteurization conditions. The stability of cocosin at different pasteurization temperatures and time duration was also evaluated for their possible application in food systems. The cocosin monomer remained intact and unaggregated at all pasteurization temperatures equal to and below $100^{\circ} \mathrm{C}$ (Fig. 6). However, at extreme temperature $\left(121^{\circ} \mathrm{C}\right.$ for $\left.15 \mathrm{~min}\right)$, cocosin was almost completely denatured.

The results of heating cocosin at different pasteurization temperatures show its relative heat stability which can be useful in the application of cocosin in fluid food systems like protein-based beverages. Whey protein concentrate (WPC) heated at $80^{\circ} \mathrm{C}$ and $134^{\circ} \mathrm{C}$ at neutral $\mathrm{pH}$ caused up to $70 \%$ losses in solubility although partial tryptic hydrolysis of WPC increased its solubility substantially (Hidalgo and Gamper, 1977). Other processing techniques have also been designed to improve the solubility of protein during processing and storage through the use of hydrocolloids like carageenan (Krawczyk et al., 2005) and other processing aids such as phosphates and sodium citrate (Shen, 2007).

In the two heating experiments conducted, small amounts of the acidic and basic subunits of cocosin were evident.

(c) Thermal denaturation by differential scanning calorimetry. Cocosin exhibited two thermal denaturation temperatures $\left(T_{\mathrm{m}}\right)$ as seen in the DSC thermogram (Fig. 7). The first thermal denaturation, characterized by the smaller peak I, occurred at a midpoint temperature of $77.6^{\circ} \mathrm{C}$. A larger peak II, which signifies a second thermal denaturation, occurred at $100.5^{\circ} \mathrm{C}$. The lower $T_{\mathrm{m}}$ may be attributed to the thermal

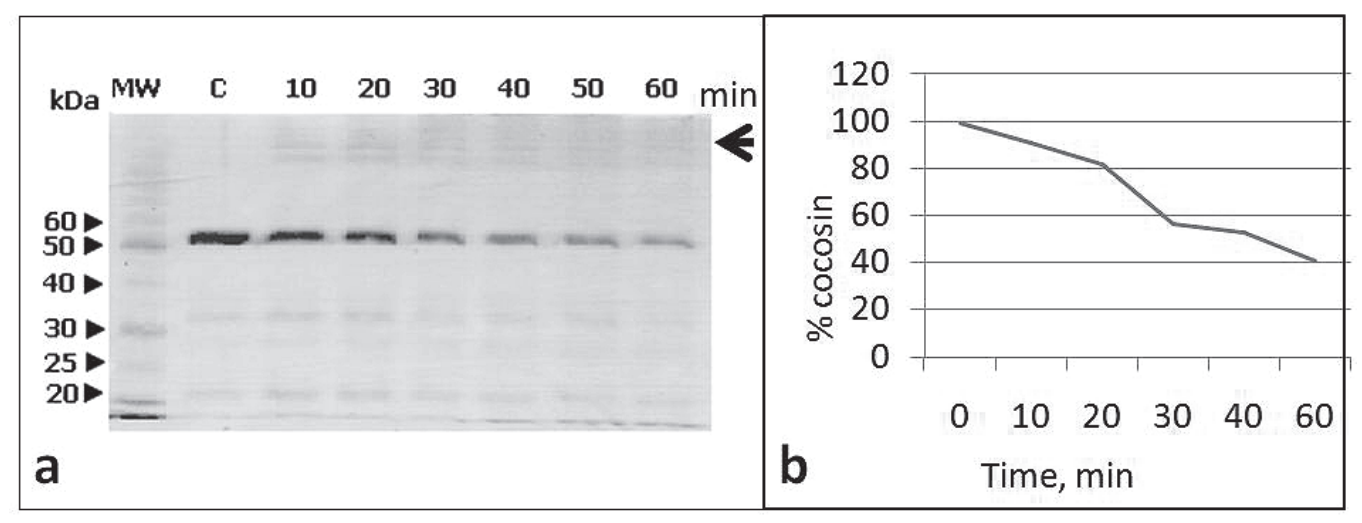

Fig. 5. SDS-PAGE profile of cocosin after incubation at $100^{\circ} \mathrm{C}$ at different time intervals.

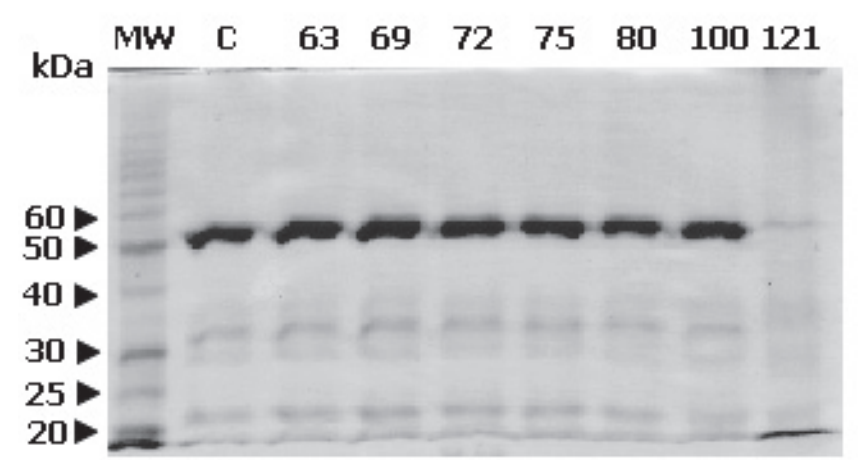

Fig. 6. Thermal stability of cocosin at different pasteurization treatments. Lane 1-molecular weight markers; Lane 2, Control; Lane 3, $63^{\circ} \mathrm{C}, 30 \mathrm{~min}$; Lane $4,69^{\circ} \mathrm{C}, 30 \mathrm{~min}$; Lane $5,72^{\circ} \mathrm{C}, 16 \mathrm{sec}$; Lane $6,75^{\circ} \mathrm{C}, 10 \mathrm{~min}$; Lane $7,80^{\circ} \mathrm{C}, 25 \mathrm{sec}$; Lane $8,100^{\circ} \mathrm{C}, 12 \mathrm{sec}$; and Lane $9,121^{\circ} \mathrm{C}, 15 \mathrm{~min}$.

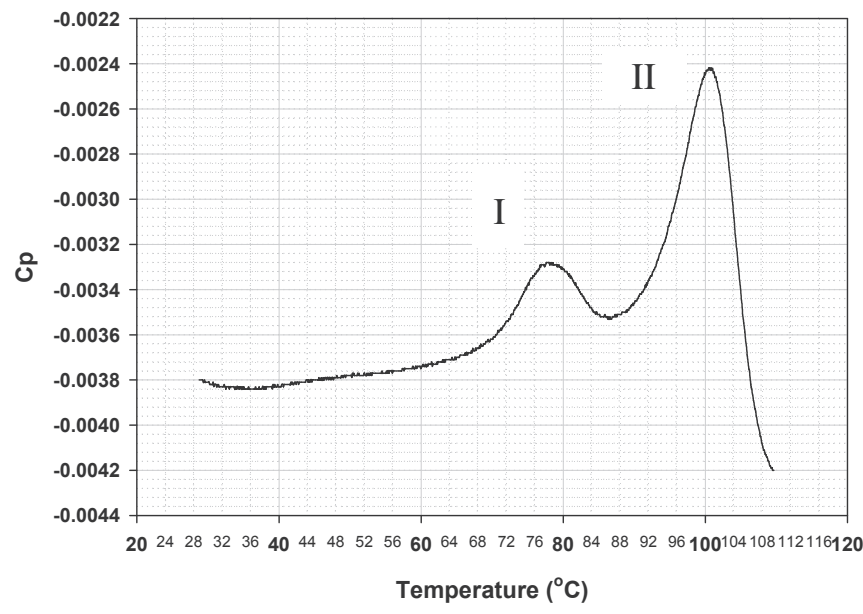

Fig. 7. Differential scanning calorimetry profile of cocosin. Peak I - trimeric cocosin; II - hexameric cocosin. 
denaturation of the trimeric form of cocosin while the higher $T_{\mathrm{m}}$ may be due to the hexameric form. Similar results were observed for group I glycinin (Maruyama et al., 2004). The observed $T_{\mathrm{m}}$ of the trimeric form of group I glycinin, with a value of $77.0^{\circ} \mathrm{C}$, was almost the same as that of cocosin. However, the denaturation of the hexameric form of group I glycinin, occurring at a peak temperature of $95^{\circ} \mathrm{C}$, was lower compared to the $100.5^{\circ} \mathrm{C}$ of cocosin. Furthermore, the $T_{\mathrm{m}}$ of native cruciferin hexamer, $86.5^{\circ} \mathrm{C}$, at $\mathrm{pH} 7.6$ and $\mu=0.50$ was also lower (Tandang et al., 2004) when compared to that of cocosin. The peaks obtained in our study had similar values but were quite sharp compared to the broad peak with two denaturation temperatures of $82^{\circ} \mathrm{C}$ and $98^{\circ} \mathrm{C}$ and an extra sharp peak at $112^{\circ} \mathrm{C}$ obtained by Kwon et al. (1996) perhaps because our sample was purified cocosin while Kwon et al. (1996) used total globulins.

Damodaran (1996) cited that heat denaturation of food proteins are not ideal as this often results into precipitation. As a consequence, functional properties that rely on solubility are greatly reduced. Nevertheless, moderate heat treatments are also beneficial since this would result in partial denaturation of proteins. Partially denatured proteins are more digestible, thus, improving the biological availability of essential amino acids.

\section{Conclusion}

The major storage protein of coconut, the $11 \mathrm{~S}$ globulin or cocosin comprising $73 \%$ of total globulins, was found to have comparable physicochemical characteristics with other $11 \mathrm{~S}$ globulins, and more interestingly, also exhibited some unique properties. Most noteworthy are its high solubility in different $\mathrm{pH}$ at $\mu=0.5$, ready digestibility of the acidic polypeptides, relative heat stability and high thermal denaturation. In addition, the excellent emulsifying behavior of cocosin in the absence of salt could be the basis for developing new processed foods. Hence, cocosin may be used as potential ingredient for food systems.

Acknowledgments The senior author (MRNA) acknowledges with gratitude the support and the study leave granted to him by the Institute of Chemistry, College of Arts and Sciences, University of the Philippines Los Baños (UPLB). The authors likewise thank the Institute of Plant Breeding, Crop Science Cluster, College of Agriculture, UPLB for the support to this project. The UPLB Basic Research Grant to RNG for this project is also deeply appreciated.

\section{References}

Balasundaresan, D., Sugadev, R. and Ponnuswamy, M.N. (2002). Purification and crystallization of coconut globulin cocosin from Cocos nucifera. Biochim. Biophys. Acta., 1601, 121-122.
Bradford, M.M. (1976). A rapid and sensitive method for the quantitation of microgram quantitites for proteins utilizing the principle of protein-dye binding. Anal. Biochem., 72, 248-254.

Carr, H.J., Plumb, G.W., Parker, M.L. and Lambert, N. (1990). Characterization and crystallization of an $11 \mathrm{~S}$ seed storage globulin from coconut (Cocos nucifera). Food Chem., 38, 11-20.

Damodaran, S. (1996). Amino acids, peptides, and proteins. In "Food Chemistry, $3^{\text {rd }}$ Edition," ed. by Fennema, O.R., Marcel Dekker, New York, pp. 322-430.

DeMason, D.A. and Sekhar, K.N.C. (1990). Electrophoretic characterization and immunological localization of coconut (Cocos nucifera L.) endosperm storage proteins. Bot. Gaz., 151, 302-313.

Ellman, G.L. (1959). Tissue sulfhydryl groups. Arch. Biochem. Biophys., 82, 70-77.

Garcia, R.N., Arocena, R.V., Laurena, A.C. and Tecson-Mendoza, E.M. (2005). The $11 \mathrm{~S}$ and $7 \mathrm{~S}$ globulins of Coconut (Cocos nucifera L.): Purification and characterization. J. Agric. Food Chem., 53, 1734-1739.

Gueguen, J., Chevalier, M., Barbot, J. and Schaeffer, F. (1988). Dissociation and aggregation of pea legumin induced by $\mathrm{pH}$ and ionic strength. J. Sci. Food Agric., 44, 167-182.

Habeeb, A.F.S.A. (1975). Reaction of protein sulfhydryl groups with Ellman's reagent. Methods Enzymol., 25, 457-464.

Hidalgo, J. and Gamper, E. (1977). Solubility and heat stability of whey protein concentrates. J. Dairy Sci., 60, 1515-1518.

Hortsmann, C. (1983). Specific subunit pairs of legumin from Vicia faba. Phytochemistry, 22, 1861-1866.

Hoshi, Y. and Yamauchi, F. (1983). Determination of sulfhydryl and disulfide contents of soybean 11S globulin and their change by lyophilization. Agric. Biol. Chem., 47, 2435-2440.

Krawczyk, G., Gisher, G., and Sewall, C. 2005. Stabilizing UHT Soy Beverages. Dairy Foods, January 10, 2005. http://www.dairyfoods.com/Articles/Ingredient_Technology/7add47062e0a7010V gnVCM100000f932a8c0 (Accessed June 2009).

Kwon, K., Bae, D., Park, K.H. and Rhee, K.C. (1996a) Aqueous extraction and membrane techniques improve coconut protein concentrate functionality. J. Food Science, 61, 753-756.

Kwon, K., Park, K.H. and Rhee, K.C. (1996b). Fractionation and characterization of proteins from coconut (Cocos nucifera L.). J. Agric. Food Chem., 44, 1741-1745.

Kwon, K. and Rhee, K.C. (1996). Emulsifying coconut proteins as a function of salt, phosphate, and temperature. JAOCS, 73, 16691673.

Laemmli, U.K. (1970). Cleavage of structural proteins during the assembly of the head bacteriophage T4. Nature, 227, 680-685.

Lakemond, C.M.M., De Jongh, H.H.J., Hessing, M., Gruppen, H. and Voragen, A.G.J. (2000). Soy glycinin: Influence of $\mathrm{pH}$ and ionic strength on solubility and molecular structure at ambient temperatures. J. Agric. Food Chem., 48, 1985-1990.

Maruyama, N., Prak, K., Motoyama, S., Choi, S., Yagasaki, K., Ishi- 
moto, M. and Utsumi, S. (2004). Structure-physicochemical function relationships of soybean glycinin at subunits levels assessed by using mutant lines. J. Agric. Food Chem., 52, 8197-8201.

Mepba, H.D. and Achinewhu, S.C. (2003). Effects of processing on protein nutritive quality of coconut Cocos nucifera products. Plant Foods Hum. Nutr., 58, 15-25.

Mills, E.N.C., Jenkins, J., Marigheto, N., Belton, P.S., Gunning, A.P. and Morris, V.J. (2002). Allergens of the cupin superfamily. Biochem. Soc. Trans., 30, 925-929.

Mohamad Ramlan, B.M.S., Maruyama, N., Adachi, M., Hontani, N., Saka, S., Kato, N., Ohkawa, Y. and Utsumi, S. (2002). Comparison of protein chemical and physicochemical properties of rapeseed cruciferin with those of soybean glycinin. J. Agric. Food Chem., 50, 7380-7385.

Mori, T., Maruyama, N., Nishizawa, K., Higasa, T., Yagasaki, K., Ishimoto, M. and Utsumi, S. (2004). The composition of newly synthesized proteins in the endoplasmic reticulum determines the transport pathways of soybean seed storage proteins. Plant J., 40, 238-249.

Reiner, C.K., Kada, G. and Gruber, H.J. (2002). Quick measurement of protein sulfhydryls with Ellman's reagent and with 4,4'-dithiodipyridine. Anal. Bioanal. Chem., 373, 266-276.

Rickert, D.A., Johnson, L.A. and Murphy, P.A. (2004). Functional properties of improved glycinin and $\beta$-conglycinin fractions. $J$. Food Sci., 69, 303-311.

Samson A.S. S.J., Khaund, R.N., Cater, C.M., and Mattil, K.F. 1971. Extractability of coconut proteins. J. Food Sci., 36, 72-728.
Shen, C. (2007). Process for making stable protein based acid beverage. United States Patent 7229659. http://www.freepatentsonline. com/7229659.html.

Shewry, P.R., Napier, J.A. and Tatham, A.S. (1995). Seed storage proteins: Structures and biosynthesis. Plant Cell, 7, 945-956.

Sjögren, B. and Spychalski, R. (1930). The molecular weight of cocosin. J. Am. Chem. Soc., 52, 4400-4404.

Soares, L.H.DB., Albuquerque, F., Assmann and Ayub, M.A.Z. (2004). Physicochemical properties of three food proteins treated with transglutaminase. Ciência Rural, 34, 1219-1223.

Staswick, P.E., Hermodson, M.A. and Nielsen, N.C. (1984). Idenfication of the cystines which link the acidic and basic components of the glycinin subunits. J. Biol. Chem., 259, 13431-13435.

Tandang, M.R.G., Adachi, M., Inui, N., Maruyama, N. and Utsumi, S. (2004). Effects of protein engineering of canola procruciferin on its physicochemical and functional properties. J. Agric. Food Chem., 52, 6810-6817.

Utsumi, S., Matsumura, Y. and Mori, T. (1997). Structure-function relationships of soy protein. In "Food Proteins and Their Applications," ed. by Damodaran, S. and Paraf, A., Marcel Dekker Inc., New York, pp. 257-291.

Venktesh, V. and Prakash, V. (1993). Functional properties of the total proteins of sunflower (Helianthus annuus L.) seed-effect of physical and chemical treatments. J. Agric. Food Chem., 41, 1823.

Wolf, W.J. (1993). Sulfhydryl content of glycinin: Effect of reducing agents. J. Agric. Food. Chem., 41, 168-176. 